\title{
Quality of Life Evaluation of Elderly People Living with HIVIAIDS According to HAT-QoL
}

\begin{abstract}
Julianne Cristinne Ferreira de Sousa ${ }^{1}$, Ana Cristina de Oliveira e Silva ${ }^{2}$ Oriana Deyze Correia Paiva Leadebal', Fabiana Ferraz Queiroga Freitas ${ }^{3}$, Ericka Silva Holmes ${ }^{4}$, Saemmy Grasiely Estrela de Albuquerque ${ }^{5}$, Deborah Rayanne Roseno de Jesus ${ }^{6}$, Renata Michele dos Santos Barreto7, Cora Coralina dos Santos Junqueira ${ }^{8}$, Camila Torres da Silva ${ }^{9}$, Cleideane Meireles da Silva Ribeiro ${ }^{10}$, Rafaela Travassos Ferreira Mascarenhas Leite ${ }^{11}$, Vanessa Laís Leão Raposo Marques ${ }^{11}$, Maria Tathiane da Silva ${ }^{11}$, Leila de Cássia Tavares da Fonsêca ${ }^{12}$, José da Paz Oliveira Alvarenga ${ }^{12}$, Juliana Barbosa Medeiros ${ }^{13}$
\end{abstract}

\section{Abstract}

Objective: Evaluating the quality of life of the elderly living with HIV/ AIDS through HAT_QoL; and characterizing the population in terms of sociodemographic and clinical data.

Methods: Cross-sectional study conducted in a specialized service clinic in the care of people living with HIVIAIDS in Paraiba. The sample was consisted by 30 people over the 60 years old living with HIVIAIDS. Data collection was conducted in July 2014 by the HAT-QoL form. Data were tabulated on an electronic spreadsheet, using the double entry technique and then analyzed through the software Statistical Package for Social Sciences version 22.0.

Results: Most of the population is male, single, between the ages of 60 and 63 years, low income and education, acquired HIVIAIDS through heterosexual contact, the quality of life was considered "good" or "very good" according to domains analyzed; observed commitment regarding the domains "sigils", "financial concern" and "sexual activity".
1 Resident Nurse in Nephrology Integrative Medicine Institute Professor Fernando Figueira. *

2 Lecturer Department of Clinical Nursing of the Federal University of Paraíba. *.

3 Doctoral Student in Nursing For the Federal University of Minas Gerais. *

4 Nurse. PhD student in Health Decision and models from the Federal University of Paraiba. *.

5 Master's Degree in Nursing from the Federal University of Paraíba. *

6 Enfermeira Specializing in Intensive Care Unit for Improvement Center and Research. *.

7 Surgical Nursing Resident Nurse Integrative Medicine Institute Professor Fernando Figueira - IMIP. *.

8 Resident Nurse Nursing in Child Health at Integral Institute of Medicine Professor Fernando Figueira - IMIP. *

9 Resident Nurse in Nephrology Integrative Medicine Institute Professor Fernando Figueira - IMIP. *.

10 Graduate nurse in nursing from the University of Pernambuco. *

11 Resident Nurse in Nephrology Integrative Medicine Institute Professor Fernando Figueira - IMIP. *

12 Lecturer Department of Clinical Nursing of the Federal University of Paraíba. *

13 Enfermeira. Specialist in Chronic Diseases Noncommunicable the Federal of Santa Catarina. *

Contact information:

Julianne Cristinne Ferreira de Sousa.

Đ julianne_cris@hotmail.com 
Conclusion: Old people had good scores in most quality of life domains. The role of nursing staff in the maintenance of these scores is essential and necessary, from early diagnosis to the possible strategies of coping disease.

\section{Keywords}

Quality of life: Elderly; HIV; Acquired Immune Deficiency Syndrome.

\section{Introduction}

The HIVIAIDS epidemic in Brazil is in its third decade, and since its inception, was associated with male homosexuals, injecting drug users and sex workers. However, recently, the epidemiology profile of the disease has shown a significant increase of cases in the group of people aged 60 years or more, in both gender.

The growing number of AIDS cases in the elderly has been associated with the aging of the Brazilian population, the increase of survival of people living with HIVIAIDS, late infection diagnosis and access to medicines for erectile disorders, a factor that has prolonged elderly sexual activity in association with the demystification of sex in the third age [1].

This expansion also relates the social, institutional, physical and psychological vulnerabilities, besides the invisibility with which is treated its exposure to the risk, whether through sex or illicit drug use. Regarding the physical and psychological vulnerabilities, they can be related to behaviors, the risk of unprotected sex practices, multiple partners, drugs and medicaments abuse, making it possible susceptibility to HIV infection [2].

Social vulnerability allows to be related to the way it is conceived the performance of sexuality in maturity and old age, once sexual activity is not restricted to biological and physical aspects, also having psychological and biographical characteristics of the individual, as well as the sociocultural context in which the elderly is inserted 3. Where the stereotypical "asexual elder", which remains rooted in society, is influencing not only the representations of old people themselves, as well as public policies and investigation programs [1].

At the institutional framework, specifically on the political and economic answers, it turns out that the investments made by the government authorities have grown in two decades of AIDS epidemic. However, considering the educational and prevention campaigns, it is noted an emphasis on specific groups such as young people and the ones in reproductive age, and according to the epidemiological needs of the moment [4].

Therefore, advances in diagnosis and treatment of HIVIAIDS have made this infection increasingly similar to those defined as chronic diseases and these advances generated a considerable impact on quality of life of people with HIVIAIDS, reducing the fear of imminence of death and improving the social, work, leisure and affective relationships quality along life $[5,6]$. Based on this understanding, researchers from different health areas have studied the quality of life, it is considered that not all the drug therapies that prolong the lives of individuals provide qualitative impact on them $[3,7,8]$.

As regard to the Quality of Life - QoL, (Qualidade de Vida - QV), this is defined by the World Health Organization - WHO, (Organização Mundial da Saúde - OMS), as the individual's perception of his position in life, within the context of culture and value systems in which it is inserted and in relation to his goals, expectations, standards and concerns [9]. There are several factors that can interfere with QoL as employment, housing, financial aspects. Health is only one of them, so researchers repor- 
ted the importance of redefining the concept when the objective is to evaluate health. In this context, it created the term "quality of life related to health" -QLRH (Qualidade de Vida Relacionada à SaúdeQVRS) [10].

In the elderly population, it is known that several factors hamper or limit QoL. The aging process tends to be marked by physiological, psychological and social changes (decline in physical performance, appearance or worsening of somatic disorders, memory difficulties, social isolation) which can provide a stressful experience and reduce QoL [11, 12].

Currently, QLRH is considered one of the most important measures in clinical studies because, among other things, it allows helping in the decision of different treatments, as well as monitoring a therapy or intervention. Its review contributes to the direction of actions that leads to improvement of living conditions, being held when the objective is to monitor the health of a certain population, to diagnose the nature, severity and prognosis of the disease, and to evaluate the treatment effects [13].

Therefore, considering the progress and what was exposed previously, there were the following questions: Which sociodemographic context are inserted the elderly living with HIVIAIDS? Do the elderly living with HIVIAIDS have good scores in the domains of Quality of Life? Answering these questions, the objectives were considered: evaluating the quality of life of older people living with HIVIAIDS through the HAT-QoL; and characterizing the study population in terms of sociodemographic and clinical data.

\section{Methodology}

Cross-sectional study realized in a reference outpatient clinic in the state of Paraíba for treatment of people living with HIVIAIDS in the city of João Pessoa. We opted for a non-probabilistic sample, consecutive composed for 30 old people. To the sample calculation was considered $p$-value of 0.10 , with $10 \%$ as sample error and $90 \%$ significance level.

Data were collected in July 2014. For the collect of sociodemographic and clinical data were used a semi-structured form formulated by the authors, and to the collect of data referring to QoL used the HAT-QoL, which consists in a specific instrument for individuals with HIVIAIDS, translated, adapted and validated for patients with HIVIAIDS in Brazil [14].

Sociodemographic data and clinical collected were typed and stored in Microsoft Office Excel 2010 spreadsheets and analyzed through simple descriptive statistics using the software Statistical Package for Social Sciences, version SPSS 22.0.

For the analyze the quality of life scores according to the HAT-QoL were assigned values from 1 to 5 for the response options offered to the questions, where the option "all the time" value 1 and "never" value [5]. Except in the fields General Activity and Health Concern that the values assigned were reversed, so, they never were value 1 . After this assigning values, it was conducted sum of questions referring to each domain, turning these values in indices, scoring them on a scale from 0 to 100 , where 100 refers to the best index. Thus, we consider as disadvantaged areas the ones which had rates lower than 60 and bad areas the ones lower than 50.

\section{Results}

The results are presented under the form of tables and relate to sociodemographic characteristics and the scores of Quality of life domains according to the HAT-QoL.

\section{Sociodemographic characteristics of old people living with HIVIAIDS}

The average age of the elderly was 65 , with a minimum age of 60 and maximum of 74 years. Among the elderly interviewed, it was found that 19 (63.3\%) were male, compared to the years of study 10 old 
people (33.3\%) had less than three years of study. Most of them set up brown $23(76.7 \%)$ and the minority, just $1(3.33 \%)$ set up as indigenous, and about the number of children, it was observed that $23(76.7 \%)$ had children (Table 01).

\section{Quality of life evaluation according to the HAT-QoL}

Most scores indicated that the answers varied from "most of the time, all the time and never", as exception of facet 1.2 domain "General activity" which

Table 1. Sociodemographic characterization of the elderly living with HIVIAIDS - João Pessoa (PB) - 2014.

\begin{tabular}{|l|c|c|}
\hline \multicolumn{1}{|c|}{ Variables } & $\mathbf{n}$ & (\%) \\
\hline Gender & & \\
\hline Male & 19 & 63.3 \\
\hline Female & 11 & 36.7 \\
\hline Age group & & \\
\hline 60-63 years old & 15 & 50 \\
\hline 63-66 years old & 06 & 20 \\
\hline 66-69 years old & 04 & 13.3 \\
\hline 69-72 years old & 02 & 6.7 \\
\hline -72 years old & 03 & 10 \\
\hline \multicolumn{1}{|c|}{ Variables } & $\mathbf{n}$ & $\mathbf{( \% )}$ \\
\hline Years of study & & \\
\hline 00-03 years & 10 & 33.3 \\
\hline 03-06 years & 06 & 20 \\
\hline 06-09 years & 01 & 3.3 \\
\hline 09-12 years & 04 & 13.3 \\
\hline 12-15 years & 07 & 23.3 \\
\hline -15 years & 02 & 6.7 \\
\hline Marital status & & \\
\hline Single & 10 & 33.3 \\
\hline Married & 08 & 26.7 \\
\hline Partner & 02 & 6.7 \\
\hline Separated & 04 & 13.3 \\
\hline Widowed & 20 \\
\hline
\end{tabular}

showed response "short time", it is important to note that some facets presented inverted sum and most of the answers were "never" for this inverted sum.

Making analysis per facets inside each domain it is observed that all domain facets' "confidence in the doctor" showed up high scores, where individuals reported that they could see the doctor whenever there was necessity (60\%) and expressed the importance of the medic demonstrated by their health (76.7\%).

\begin{tabular}{|c|c|c|}
\hline Variables & $n$ & $(\%)$ \\
\hline \multicolumn{3}{|l|}{ Ethnicity } \\
\hline White & 06 & 20 \\
\hline Brown & 23 & 76.7 \\
\hline Indigenous & 01 & 3.3 \\
\hline \multicolumn{3}{|l|}{ Children } \\
\hline Yes & 23 & 76.7 \\
\hline No & 07 & 23.3 \\
\hline \multicolumn{3}{|l|}{ Sexual orientation } \\
\hline Heterosexual & 27 & 90 \\
\hline Homosexual & 02 & 6.7 \\
\hline Bisexual & 01 & 3.3 \\
\hline \multicolumn{3}{|l|}{ Viral load } \\
\hline < 50 (Undetectable) & 28 & 93.4 \\
\hline 50 a 100.000 & 01 & 3.3 \\
\hline 100.000 a 200.000 & 01 & 3.3 \\
\hline \multicolumn{3}{|l|}{ Cells T CD4 } \\
\hline$>350$ cells mm3 & 29 & 96.7 \\
\hline 200 a 350 cells mm3 & 01 & 3.3 \\
\hline \multicolumn{3}{|l|}{ Family income } \\
\hline 1 minimum wage & 21 & 70 \\
\hline 2 a 3 minimum wage & 01 & 3.3 \\
\hline 4 a 10 minimum wage & 03 & 10 \\
\hline 11 a 20 minimum wage & 01 & 3.3 \\
\hline Above 20 minimum wage & 01 & 3.3 \\
\hline
\end{tabular}

Source: Field research, João Pessoa, 2014 
As for the domain "Sexual activity" notes up high scores in all facets knowing that this domain responses have inverted value. On "Financial Concern" domain, it is observed that most of the elderly does not demonstrate financial concern and they say they do not have concerns about living with a determined income (63.3\%).

Table 2. Scores Distribution of facets of Quality of life about women living with HIVIAIDS according to the HATQoL- João Pessoa (PB) $-2014$

\begin{tabular}{|c|c|c|}
\hline Domains according to HATQOL & Respond & $\%$ \\
\hline \multicolumn{3}{|l|}{ General activity } \\
\hline Satisfied with my physical activity & $\begin{array}{l}\text { All the } \\
\text { time }\end{array}$ & 60 \\
\hline $\begin{array}{l}\text { Physically limited to perform routine } \\
\text { household chores }\end{array}$ & $\begin{array}{l}\text { Short } \\
\text { time }\end{array}$ & 40 \\
\hline $\begin{array}{l}\text { The pain limited my ability to be } \\
\text { physically active }\end{array}$ & Never & 73.3 \\
\hline $\begin{array}{l}\text { No longer able to carry out my daily } \\
\text { activities as before }\end{array}$ & Never & 73.3 \\
\hline $\begin{array}{l}\text { Limited the amount of work that I am } \\
\text { able to carry on my daily activities }\end{array}$ & Never & 60 \\
\hline I felt too tired to social activities & Never & 60 \\
\hline \multicolumn{3}{|l|}{ Satisfaction with life } \\
\hline Enjoyed my life & $\begin{array}{l}\text { All the } \\
\text { time }\end{array}$ & 46.7 \\
\hline I felt in control of my life & $\begin{array}{l}\text { All the } \\
\text { time }\end{array}$ & 80 \\
\hline $\begin{array}{l}\text { I was pleased with my level of social } \\
\text { activities }\end{array}$ & $\begin{array}{l}\text { All the } \\
\text { time }\end{array}$ & 63.3 \\
\hline I was pleased for having been so healthy & $\begin{array}{l}\text { All the } \\
\text { time }\end{array}$ & 70 \\
\hline \multicolumn{3}{|l|}{ Health concerns } \\
\hline $\begin{array}{l}\text { I was not able to live the way I wanted } \\
\text { for being worried about my health }\end{array}$ & Never & 46.7 \\
\hline I was worried about my CD4 count & Never & 76.7 \\
\hline I was worried about my viral load & Never & 83.3 \\
\hline $\begin{array}{l}\text { I was worried, wondering when } \\
\text { I would die }\end{array}$ & Never & 93.3 \\
\hline
\end{tabular}

The domain "Regarding to medication by HIV" is observed that most of interviewees have no difficulty in adhering to antiretroviral therapy (66.7\%) and do not care about the possible side effects (56.7\%). On "Sexual activity" domain, it is noted that most of them have difficulty to get excited (76.7\%) and to reach orgasm (73.3\%). (Table 2 )

\begin{tabular}{|c|c|c|}
\hline Domains according to HATQOL & Respond & $\%$ \\
\hline \multicolumn{3}{|l|}{ Financial concern } \\
\hline $\begin{array}{l}\text { I was concerned about the possibility of } \\
\text { having to live with a certain income }\end{array}$ & Never & 63.3 \\
\hline I was worried if I had to pay my bills & Never & 60 \\
\hline $\begin{array}{l}\text { I had little money to take care of myself } \\
\text { the way I think right }\end{array}$ & Never & 53.3 \\
\hline \multicolumn{3}{|l|}{ In relation to medication for HIV } \\
\hline Taking my meds has been a burden & Never & 66.7 \\
\hline $\begin{array}{l}\text { Taking my medicine hampered me to } \\
\text { lead a normal life }\end{array}$ & Never & 83.3 \\
\hline $\begin{array}{l}\text { My medications have caused unpleasant } \\
\text { side effects }\end{array}$ & Never & 56.7 \\
\hline $\begin{array}{l}\text { I was not sure as for the reasons which } \\
\text { lead me to take medicine }\end{array}$ & Never & 8 \\
\hline
\end{tabular}

\begin{tabular}{|c|c|c|}
\hline \multicolumn{3}{|l|}{ HIV awareness } \\
\hline $\begin{array}{l}\text { I regretted the way I took my life before I } \\
\text { knew had HIV }\end{array}$ & Never & 63.3 \\
\hline $\begin{array}{l}\text { I was angry with HIV exposure behavior I } \\
\text { adopted in the past }\end{array}$ & Never & 66.7 \\
\hline \multicolumn{3}{|l|}{ Concern with secrecy } \\
\hline $\begin{array}{l}\text { I limited what I say to others about } \\
\text { myself }\end{array}$ & $\begin{array}{l}\text { All the } \\
\text { time }\end{array}$ & 50 \\
\hline $\begin{array}{l}\text { I was afraid to tell other people that I } \\
\text { have HIV }\end{array}$ & $\begin{array}{l}\text { All the } \\
\text { time }\end{array}$ & 63.3 \\
\hline $\begin{array}{l}\text { I was worried that my family found out I } \\
\text { have HIV }\end{array}$ & $\begin{array}{l}\text { All the } \\
\text { time }\end{array}$ & 60 \\
\hline $\begin{array}{l}\text { I was worried that people's day-to-day } \\
\text { found out that I have HIV }\end{array}$ & $\begin{array}{l}\text { All the } \\
\text { time }\end{array}$ & 60 \\
\hline $\begin{array}{l}\text { I was worried about losing my source of } \\
\text { income find out I have HIV }\end{array}$ & $\begin{array}{l}\text { All the } \\
\text { time }\end{array}$ & 2 \\
\hline
\end{tabular}




\begin{tabular}{|c|c|c|}
\hline Domains according to HATQoL & Respond & $\%$ \\
\hline \multicolumn{3}{|l|}{ Confidence in the doctor } \\
\hline $\begin{array}{l}\text { I felt I could see my doctor whenever I } \\
\text { needed or felt the necessity }\end{array}$ & $\begin{array}{l}\text { All the } \\
\text { time }\end{array}$ & 60 \\
\hline $\begin{array}{l}\text { I felt that my doctor consulted me to take } \\
\text { decisions about my treatment }\end{array}$ & $\begin{array}{l}\text { All the } \\
\text { time }\end{array}$ & 73.3 \\
\hline I felt that my doctor cares about me & $\begin{array}{l}\text { All the } \\
\text { time }\end{array}$ & 76.7 \\
\hline \multicolumn{3}{|l|}{ Sexual activity } \\
\hline It was hard to get sexually aroused & $\begin{array}{l}\text { All the } \\
\text { time }\end{array}$ & 76.7 \\
\hline It was difficult to reach orgasm & $\begin{array}{l}\text { All the } \\
\text { time }\end{array}$ & 73.3 \\
\hline
\end{tabular}

The evaluation of quality of life according to the HATQoL the elderly living with HIVIAIDS had higher scores in the domains "Confidence in the doctor" and "General Activity". It is observed that the domain "Sexual activity" had the lowest score in relation to other domains. (Table 3)

It is important to highlight that most of the domains about Quality of life according to the HATQoL showed high scores with exception for the domains "Financial Concern" and "Sexual activity".

Table 3. Distribution of the scores of Quality domains of life of older people living with HIVIAIDS according to the HATQoL- João Pessoa (PB) - 2014.

\begin{tabular}{|l|c|c|c|c|c|c|}
\hline \multicolumn{1}{|c|}{ Domains } & $\begin{array}{c}\text { Number of } \\
\text { items }\end{array}$ & Average & Median & Minimum & Maximum & $\begin{array}{c}\text { Standard } \\
\text { Deviation }\end{array}$ \\
\hline General activity & 6 & 73.8 & 72.0 & 25 & 100 & 10 \\
\hline Satisfaction with life & 4 & 70.5 & 75.0 & 8.5 & 100 & 21 \\
\hline Health concerns & 4 & 60.1 & 60 & 0 & 100 & 31 \\
\hline Financial concern & 3 & 58.6 & 40 & 0 & 100 & 27 \\
\hline In relation to medication for HIV & 5 & 67.8 & 64 & 0 & 100 & 20.2 \\
\hline HIV awareness & 2 & 68.0 & 66.7 & 0 & 100 & 23 \\
\hline Concern with secrecy & 5 & 47.6 & 48 & 0 & 100 & 21.8 \\
\hline Confidence in the doctor & 3 & 94.7 & 90 & 0 & 100 & 33 \\
\hline Sexual activity & 2 & 33.6 & 30 & 0 & 100 & 20.3 \\
\hline
\end{tabular}

Source: Field research. João Pessoa. 2014.

\section{Discussion}

According to Table 1, half of the interviewed people were aged 60-63 years (50\%). The majority were male $(63.3 \%)$, but the amount of women (36.7\%) compared to infected men differs in only 8 people, representing a high number of women in proportion to men, these data corroborate with studies in the same department where the sample consists of men (57\%) and women (43\%). Most of the participants are also male, but results indicated that the proportion of infected men for each woman is less than two, reflecting the epidemiological trend of the disease in the country, so, the "feminization" of AIDS [15]. It is observed that the reason between the genders in Brazil has been decreasing steadily, reconfirming the change in the epidemiological profile of HIVIAIDS [16].

It stands out even in this study, the amount of unmarried population (33.3\%) and low education (33.3\%) between $0-3$ years of schooling and avera- 
ge income until 1 minimum wage (70\%). A study in a city in the countryside of São Paulo, on the quality of life of individuals with HIVIAIDS and its relationship to sociodemographic factors and related to sexuality, we interviewed 228 individuals with HIVIAIDS, where 53.5\% were men and $46.5 \%$ women. There was also a low level of education of the studied population, because $46.6 \%$ had not completed primary school (less than eight years of study) and 5.3\% were illiterate [17]. Corroborating this study regarding the spread of infection in the male population, with low education and income, which still constitutes as most of the population infected with HIVIAIDS. Thus, it is possible to realize that the sociodemographic characteristics of the sample are similar to those of people living with HIVIAIDS studied in Brazil, under the theme quality of life.

As shown in Tables 2 and 3, the study found that the quality of life of old people living with HIV/ AIDS is very good, as the General activity domain is high, in a score of $73.8 \%$. It can be related to the Satisfaction with life domain that is with a score of $70.5 \%$. From the analysis of the domains, it can be inferred that the physical ability and disposition of the elderly, his self-control and preserved interpersonal relationship are considered essential for life satisfaction in this age group, so seniors with less impaired physical integrity would have greater satisfaction with their lives and, in turn, a better quality of life $[18,19]$.

We still highlight the domain that discusses about "Confidence in the doctor", showing a score of $94.7 \%$, reflecting the good quality of professional care provided to this population. During the interviews it was clear satisfaction with the health service to these users, as the compliments and expressions of well-being and safety to report, not just about their doctors, but about the entire health care team, was present in totality of the people interviewed, to address the aspects related to this domain.
Confidence in the doctor is situation of demonstration of faith that the patient puts on professional, motivated by an attuned therapeutic relationship $[3,15,17]$. An effective professional relationship health-user has influenced the course of treatment, associated with better health conditions and a higher level of adherence to the therapeutic. This close relationship may have been a factor that contributed in the correlation cited above, and that may also have led the elderly to submit more life satisfaction and better conditions in the domain "General activities" [3].

The good performance in this area tends to reflect on the structure and quality of health care reference to people living with HIVIAIDS available in the public system. Brazil is a model country talking about the care and support to people living with HIVIAIDS, providing a multidisciplinary reference services for prevention, diagnosis and treatment of HIVIAIDS with free offering of antiretroviral, still counting the participation of non-governmental organizations to support people living with HIV/AIDS [5].

The domain "In relation to medication for HIV" is observed that most interviewees do not have difficulty in adhering to antiretroviral therapy and worries about the possible side effects. This domain may be directly linked with the quality of health services offered to this population and the domain "Confidence in the doctor" as a reflection of good adhesion and understanding the necessity to use this medication, reinforcing the justification described above.

Scholars of quality of life of people living with HIVIAIDS elucidate the quality of life of individuals decays to as the aging occurs $[15,17]$, however, this study shows the opposite, since, except for the areas relating to "Sexual activity" and "Concern with secrecy". It is observed high scores in all facets, knowing that in these domains the answers have inverted value. The particularity of the "Sexual activity" domain refers to sexual inactivity reported by most interviewees, especially those who declared 
themselves widowed or single. Despite the sexual changes in course, sexuality is far from being seen as healthy and natural in the elderly. Prejudice and lack of information reinforce the idea of asexual old age [2].

Sexuality is an aspect of life greatly compromised by the impact of HIV seropositivity and the emotional and social consequences associated with it. The diagnosis of HIV infection can result in loss of libido and cessation or reduction of sexual activity. In addition, people living with HIV/AIDS still face the fear of HIV transmission for (a) partner (a) and difficulty to talk about sexuality with health professionals [17].

As for the low score (47.6\%) in the field "Concern with secrecy", this was due to the fear that the majority of the elderly interviewed in revealing seropositive mainly for fear of stigma and prejudice, as well as rejection by people close to them, fear that, in advance, got clear at the time of the invitation to participate of the interview because even before knowing the contents of the free and clarified consent term, most seniors showed tension as mention of their names in the course research.

The elderly showed limit what they say about themselves, especially when it comes to strangers to their conviviality, or to more distant relatives, establishing a limited number of people, usually very close family members to have knowledge about their HIV positive status, but they did not reveal concern about the facet that refers to the possibility of losing their source of income with the discovery of positivity of HIV infection, being justified by financial stability arising with the retirement or benefit gained.

In agreement with these results, the literature indicates that this domain has lower scores, revealing the fear and concern about the secrecy of HIV infection in their social environment, and among everyday people and co-workers. In the study in two units of the municipal health system of Ribeirão Preto - SP was evident the concern of individuals interviewed by the revelation of their diagnosis of having HIVIAIDS, demonstrating the problems related to stigma, discrimination and prejudice in the lives of these individuals [17].

Many people living with HIVIAIDS opt for secre$c y$, limiting the maximum the number of people who know their HIV status, adopting a "double life" because only a few are chosen to learn of their infection. However, other individuals are obligated to pretend or lie about important aspects of their lives, facing embarrassing situations, like lying to go to the doctor, hide or use stealth to take medicines, face the fear of being identified as HIV positive in the service health, generating a clandestine themselves that affects their lives in various aspects: emotional, professional, social and even in the way they conduct their own treatment [20].

However, in old age, the quality of life appears to be linked only to the absence of disease and disability, but also to positive resources available in the environment and good psychological status of the elderly, which entails the use of more appropriate and effective strategies of coping [21]. On the domain of "Financial Concern" is observed that most of the elderly do not demonstrate financial concern and say they do not have concerns about living with predetermined income.

Financial stability is stated in the sense of being retired or receiving benefits and judge these sources of income as sufficient to meet their needs, even up adding to the free treatment for HIV and free accessibility to other medications such as antihypertensives, antiglycemic, antilipemics. Only the fact of being retired was positively associated with better scores.

In several areas (financial concern, concern about health, issues relating to medication, general activity, sexual activity and satisfaction with life) of HATQoL the best QoL were associated with better life conditions, observed by the categories of higher income and education variables and have emplo- 
yment. These results corroborate the ones found in other studies that showed that low-income and poor education and unemployment are factors associated with worse QoL [17].

\section{Final Considerations}

Among the portrayed peculiarities in this study, it highlights the importance of physical integrity and continuity of the self-regulatory mechanisms of personality, autonomy and social participation, financial stability, quality of health care provided to the old population in determining of a good quality of life for old people living with HIVIAIDS, and these outweigh the positive HIV status.

Participants in this study presented scores of quality of life good to very good. Today, we come across with an individual living with a chronic condition that needs to be accompanied as other individuals with other chronic diseases, without prejudice, without discrimination and without ideation of death, but of long life with periods of relapse and remission to dependent care and reorganization of habits and lifestyle.

However, it is essential that the training of health professionals address the chronicity of HIVIAIDS and their significant changes due to the new perspectives of life, the new meanings attributed by HIVIAIDS infection, focused not only on the issue of death, still present in the social imaginary. It is necessary a different look to this population due the exposed vulnerabilities in the study, becoming imperative the change in the way of acting of professional and health services towards the clinical changes of the disease and the establishment of other health problems arising with advancing age it is also necessary to cause changes in the reception and care of these users.

Developing research involving this thematic where it evaluates the quality of life brings important social and scientific contributions, despite the reduced number of studies involving these issues.
In this context, nursing has a fundamental role in the quality of life of individuals, from early diagnosis to the possible coping strategies of the disease. For achieving of a better quality of life, it is critical an interdisciplinary approach so that it can watch these individuals with views to integrality of health care.

\section{References}

1. Butin, NG. Finitude e envelhecimento: significados da morte no idoso soropositivo [Dissertação de Mestrado]. Pontifica Universidade Católica de São Paulo; 2002.

2. Santos AFM, Assis M. Vulnerabilidade das idosas ao HIV/AIDS: despertar das políticas públicas e profissionais de saúde no contexto da atenção integral: revisão de literatura. Rev. Bras. Geriatr. Gerontol. 2011; 14(1): 147-57.

3. Galvão MTG, Cerqueira ATAR, Machado JM. Avaliação da qualidade de vida de mulheres com HIV/aids através do HatQoL. Cad. Saúde Pública. 2004; 20(2): 430-37.

4. Ayres JRCM, França Jr I, Calazans GJ. AIDS, vulnerabilidade e prevenção. II Seminário saúde reprodutiva em tempos de AIDS Rio de Janeiro: IMS/UERJ - ABIA. 1997; 20-37.

5. Carvalho FT, Morais NA, Koller SH, Piccini CA. Fatores de proteção relacionados à promoção de resiliência em pessoas que vivem com HIVIAIDS. Cad. Saúde Pública. 2007; 23(9): 2023-33.

6. Seidl EMF, Zannon CMLC, Tróccoli BT. Pessoas vivendo com HIV/AIDS: enfrentamento, suporte social e qualidade de vida. Psicologia: Reflexão e Crítica. 2005; 18(2): 188-95.

7. Gortado DRM. Qualidade de vida e transplante hepático: Avaliação comparativa em diferentes fases pré e pós cirurgia. [Tese de doutorado] - Faculdade de Medicina de São Paulo; 2007. $127 f$.

8. Neves LAS, Canini SEM, Reis RK, Santos CB, Gir E. Aids e tuberculose: a coinfecção vista pela perspectiva da qualidade de vida dos indivíduos. Rev. Esc. Enferm. USP. 2012; 46(3): 704-10.

9. WHO-World Realth Organization. Contry protocol for developing the who quality of life (WHOQOL): HIV/aids module. 1997, WHO, Genebra.

10. Pagani TCS, Pagani Jr CR. Instrumentos de avaliação da qualidade de vida relacionada à saúde. Rev. Ciências Bio. 2005; 69: 32-7.

11. Geocze L, Mucci S, Marco MA, Nogueira-Martins LA, Citero VA. Qualidade de vida e adesão ao tratamento anti-retroviral de pacientes portadores de HIV. Rev. Saúde Pública.2010; 44(4): 743-9. 
12. Melo, RLP, Eulálio, MC, Silva HDM, Filho, JMS, Gonzaga, PS. Sentido de vida, dependência funcional e qualidade de vida em idosos. Rev. Bras. Geriatr. Gerontol. 2013; 16(2): 239-50.

13. Kluthcovsky, ACGC. Takayanagui, AMM. Qualidade de vida: aspectos conceituais. Revista Salus-Guarapuava. 2007; 1(1): 13-5.

14. Soárez PC, Castelo A, Abrão P, Holmes WC, Ciconelli RM. Tradução e validação de um questionário de avaliação de qualidade de vida em AIDS no Brasil. Rev Panam Salud Pública. 2009; 25(1): 69-76.

15. Silva J, Saldanha AAW, Azevedo RLW. Variáveis de impacto na qualidade de vida de pessoas acima de 50 anos HIV+. Psicologia: Reflexão e Crítica. 2010; 23(1): 56-63.

16. Ministério da Saúde (Brasil). Boletim Epidemiológico Aids e DST. Secretaria de Vigilância em Saúde. Programa Nacional de DST e Aids; 2007.

17. Reis RK, Santos CB, Dantas RAS, Gir E. Qualidade de vida, aspectos sociodemográficos e de sexualidade de pessoas vivendo com HIVIAIDS. Texto Contexto Enferm. 2011; 20(3): 565-75.

18. Jakobsson $U$, Klevsgard $R$, Westergren A, \& Hallberg IR. Old peoplein pain: A compatative study. Journal of Painand Symptom Management. 2003; 26: 625-36.

19. Neri AL. Maturidade e velhice. Campinas, SP: Papirus; 2001.

20. Cedaro JJ. A ferida as alma: os doentes de aids sob o ponto de vista psicanalítico. [Tese de Doutorado] - Instituto de Psicologia, Universidade de São Paulo, São Paulo, 2005. $259 f$

21. Beckert M, Irigaray TQ, Trentini CM. Qualidade de vida, cognição e desempenho nas funções executivas de idosos. Estud. Psicol. 2012; 29(2): 155-62.

Publish in International Archives of Medicine

International Archives of Medicine is an open access journal publishing articles encompassing all aspects of medical science and clinical practice. IAM is considered a megajournal with independent sections on all areas of medicine. IAM is a really international journal with authors and board members from all around the world. The journal is widely indexed and classified Q1 in category Medicine. 